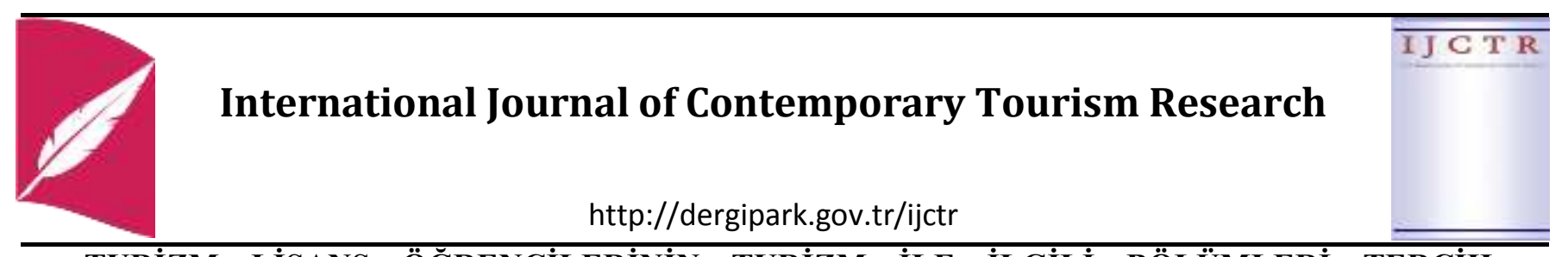

TURİM LİSANS ÖĞRENCÍLERİNIN TURİZM İLE ÍLGİL̇ BÖLÜMLERİ TERCİH
NEDENLERİ
Araştırma Makalesi

Seher KONAK*, Yunus ÖZHASAR**

\title{
ÖZET
}

Son yıllarda turizm ile ilgili bölümlere açılan kontenjanların doluluk oranlarında düşüşler ve farklılıklar gözlenmektedir. Bu çalışmanın amacı, 2018 YKS yerleştirme sonucunda kayıt yaptıran ve turizm ile ilgili bölümleri tercih eden öğrencilerin tercih nedenlerinin belirlenmesidir. Bu amaçla, saha araştırması Anadolu Üniversitesi, Osmangazi Üniversitesi, Adnan Menderes Üniversitesi ve Gazi Üniversitesi Turizm Fakültesine kayıt yaptıran öğrencilerden katılım isteği gösteren 406 öğrenci ile 1 Kasım-10 Aralık 2018 tarihleri arasında anket tekniği ile gerçekleştirilmiştir. Araştırmaya katılan öğrencilerin \%67,5'inin bu mesleği isteyerek seçtiği; \%66,5'inin ilk beş tercihinden birisinin turizm olduğu tespit edilmiştir. Katılımcıların yalnızca \%12,3'ü turizm meslek lisesi mezunudur. Diğer lise türlerinden mezun olan öğrenciler de turizm mesleğini tercih etmişlerdir. Ayrıca, katılımcıların \%44,8'i üniversite tercihinde üniversitenin bulunduğu şehir faktörünü göz önünde bulundurduklarını belirtmişlerdir. Araştırmada frekans analizinin yanı sıra faktör ve güvenirlik analizleri yapılmış olunup, bulgulara yer verilmiştir. Sonuç olarak, katılımcıların bölüm tercih nedenlerine bakıldığında sektörde çalışma isteği $(\% 33,3)$ oranında ilk sırayı alırken; üniversite tercih nedenlerine bakıldığında şehir faktörü $(\% 44,8)$ oranında ilk sırayı almaktadir.

Anahtar Kelimeler: Turizm Eğitimi, Turizm Mesleği, Turizm Fakültesi

JEL Sinıflama Kodları: L83; I21

\section{THE REASONS OF WHY TOURISM UNDERGRADUATE STUDENTS CHOOSE THE DEPARTMENTS OF TOURISM}

Research Article

\begin{abstract}
In recent years, it has been seen that there are decreases and differences in the occupancy rates of the quotas which are related to tourism departments in the university. The aim of this study is to determine the reasons of preference of students who enroll in the 2018 YKS placement and who prefer the departments related to tourism. For this purpose, field survey was conducted to 406 students who were enrolled to Anadolu University, Osmangazi University, Adnan Menderes University and Gazi University Tourism Faculty. Survey is done during 1 November and 10 December 2018 period. According to results: $67,5 \%$ of the students who participated in the study they said they willingly chose this profession; $66,5 \%$ of the students who participated to survey, tourism was one of the first five choices for them to enroll university. Only $12,3 \%$ of the participants were graduated from tourism vocational high school. Students who graduated from a different kind of high school also preferred the tourism profession. In addition, $44,8 \%$ of the
\end{abstract}

\footnotetext{
* Araş. Gör. Dr., Osmangazi Üniversitesi, Turizm Fakültesi, skonak@ogu.edu.tr, orcid.org/ 0000-0002-6847-9754

**Araş. Gör., Osmangazi Üniversitesi, Turizm Fakültesi, yozhasar@ ogu.edu.tr, orcid.org/ 0000-0003-1892-321X

“Konak S. ve Özhasar Y. (2019). Turizm Lisans Öğrencilerinin Turizm İle İlgili Bölümleri Tercih Nedenleri, International Journal of Contemporary Tourism Research, Vol 3: No: 1, p1-11, doi: 10.30625/ijctr.525435" 
participants stated that they consider the city factor is another reason why they selected tourism. In addition to frequency analysis, factor and reliability analyses have been done and findings have been included in the study. As a result, considering the reasons for the preference of the participants, the desire to work in the sector $(33,3 \%)$ was the first. When the reasons of university preference are considered, city factor $(44,8 \%)$ takes the first place.

Keywords: Tourism Education, Tourism Profession, Faculty of Tourism

JEL Classification Code: L83; I21

\section{GíRiș}

Meslek seçimi insanların bütün hayatını etkileyen önemli dönüm noktalarından biridir. Çünkü meslek seçimi kişinin yalnızca çalışma sahasını değil bununla birlikte hayatını ve geleceğini etkileyecek pek çok önemli unsuru da içerir (Karaman, Metin ve Güven, 2017, s.859). Önemli bir kitle için bu dönüm noktası üniversite tercihi sürecinde kendini göstermektedir. Üniversite ve bölüm tercihi, kişinin alternatif üniversiteler ve bölümler arasında kendisi için en uygun olanı seçmesi olarak görülse de kimi zaman bu süreç birçok değişkenin etkisi ile farklı bir boyut kazanabilir (Zengin ve Uzut, 2017, s.18). Örneğin, Savickas (1991) meslek seçimini etkileyen faktörleri yetenek, ilgi, değer ve inanç sistemi, aile, kültür ve çevre olarak ifade eder (Owen vd., 2012, s.135). Ancak bölüm ve üniversite tercihi söz konusu olduğunda, bireylerin ilgili geçiş sınavdan aldıkları puan, maddi durum, ekonomik uzaklık, üniversitenin imaj1, kampüs imkânları gibi faktörler de devreye girer. Tüm bunların yanı sira bireylerin lisans seviyesinde eğitim aldıkları bölümlerin dışındaki bir alanda çalıştığ 1 da sıklıkla gözlenen bir durumdur. İstemediği bir bölümü tercih eden kişilerin mezun olmadan önce veya mezun olduktan sonra kendi alanı dışında çalıştıkları görülmektedir (Erdinç ve Kahraman, 2012, s.230). Turizm bölümü söz konusu olduğunda da bu durumdan bahsetmek mümkündür. Avcıkurt ve diğerlerinin (2012) Balıkesir Turizm İşletmeciliği ve Otelcilik Yüksekokulu mezunları özelinde yaptıkları araştırmada, katılımcıların yalnızca \%31'inin turizm sektöründe çalıştıkları anlaşılmıştır. $\mathrm{Bu}$ çalışmada ise turizm lisans öğrencilerinin turizm ile ilgili bölümleri tercih etmelerinde etkili olan faktörlerin neler olduğunun tespit edilmesi amaçlanmaktadır.

Son yıllarda yapılan çalışmalar turizm sektörünün istihdama katkısının yaklaşık \%8 olduğunu göstermektedir (Şit, 2016, s.110). Aynı zamanda turizm sektöründen elde edilen gelir Türkiye'nin dış ticaret açı̆̆ını da önemli ölçüde karş1lamaktadır. Örneğin, 2017 y1lında turizmden elde edilen 26.283.656 dolarlık gelir diş ticaret açığının \%34.25'ine denk gelmektedir (www.tursab.org.tr). $\mathrm{Bu}$ bağlamda, hizmet sektörünün bir kolu olan turizmde yetişmiş kalifiye eleman son derece önemli bir ihtiyaçtır. $\mathrm{Bu}$ ihtiyacın giderilmesine yönelik çok sayıda fakülte ve yüksekokul kurulmuştur (Keleş, 2017, s.143). Yapılan araştırmalar turizm eğitimi alan öğrencilerin önemli bir bölümünün turizm sektöründe çalışmak istemediklerini veya çalışmadıklarını göstermektedir. Eğitilmiş personelin sektörde istihdam edilememesinin birçok nedeni vardır. Bunlardan bazıları, kariyer imkânlarının yetersizliği veya öğrencilerin sektöre bakış açılarının olumsuz olmasıdır (Duman, Tepeci ve Unur, 2006, s.52). Bu bağlamda, öğrencilerin tercih esnasında bölüm tercihlerini etkileyen birçok faktör bulunmaktadır. $\mathrm{Bu}$ araştırmada lisans eğitimine yeni başlayan öğrencilerin, turizm ve ilgili bölümlerini tercih etmelerinde etkili olan faktörler saptanmaya çalışılmıştır.

\section{TÜRKIYE'DE TURIZM EĞİTIMI}

Eğitim; yeni kuşakların, toplum yaşayışında yerlerini almak için hazırlanırken gereken bilgi, beceri ve anlayışlar elde etmelerine ve kişiliklerini geliştirmelerine yardım etmek etkinliğidir (Başaran 1992'dan akt. Tuyluoğlu, 2003). Türkiye'de turizm eğitimi; örgün ve yaygın olmak üzere iki şekilde gerçekleştirilmektedir (Ünlüören ve Boylu, 2005, s.15). 1950'li y1llarda kamu kuruluşlarınca düzenlenen kurslar aracılığıyla verilmeye başlanan turizm eğitimi (Keleş, 2017, s.144) ilerleyen yıllarda ortaöğretim ve yükseköğretim düzeyinde verilmeye başlanmıştır (Üzümcü, Alyakut ve Günsel, 2015, s.179). Günümüzde ise hemen her şehirde turizm eğitimi veren bir yükseköğretim kurumu bulmak mümkündür. 2018 y1lı Yükseköğretim Kurumlanı Sınavı sonrasında ön lisans ve lisans dâhil toplamda 123 üniversite, 295 birim, 488 bölüm ve 600 programda turizm ve turizm ile ilgili bölümlere kontenjan açılmıştır (Tuna, Başoda ve Aylan, 2018, s.67). Yaygınlaşan 
turizm eğitimine paralel olarak turizm eğitiminin niteliği, turizm eğitimi alan bireylerin sektördeki istihdamı, turizm eğitimi almak üzere tercihte bulunan öğrencilerin tercih sebepleri gibi konularda alanyazında incelenmeye başlanmıştır. $\mathrm{Bu}$ konuda yapılmış bazı çalışmalar aşağıda gösterilmektedir (Bkz. Tablo 1).

\section{Tablo 1. Türkiye'de Turizm Eğitimi Alan Öğrencilerle Yapılmıș Çalıșmalar}

\begin{tabular}{|c|c|}
\hline Kuşluvan (2000) & $\begin{array}{l}\text { ğrencilerin büyük çoğunluğunun turizmi gönüllü olarak tercih ettiği görülmüştür. Bununla } \\
\text { irlikte öğrencilerin \% \% } 48 \text { 'i turizm sektörü ile ilgili bilgi sahibi olmaları halinde yine de turizm } \\
\text { olümünü tercih edeceklerini ifade etmiştir. }\end{array}$ \\
\hline $\begin{array}{l}\text { Kozak ve } \\
\text { Kizılırmak (2001) }\end{array}$ & $\begin{array}{l}\text { urizm sektörüne karşı olan tutumun cinsiyet, mezun olunan lise, üniversite tercih sırası gibi } \\
\text { nsurların etki etmediği ancak staj yapıp yapmama durumunun etkilediği tespit edilmiştir. Staj } \\
\text { apan öğrencilerin yapmayanlara göre daha olumsuz tutumlar içinde bulunduğu görülmüştür. }\end{array}$ \\
\hline $\begin{array}{l}\text { Kuşluvan ve } \\
\text { Kuşluvan (2003) }\end{array}$ & $\begin{array}{l}\text { urizmde lisans eğitimi veren } 7 \text { okulda } 3 \text {. ve } 4 \text {. Sınıfta okuyan ve sektörde en az } 3 \text { ay çalışmış } \\
\text { lan öğrencilerle yaptıkları çalışmada } \% 51 \text { oranında turizmde çalışmayı saygın bir meslek olarak } \\
\text { orrmediklerini, } \% 50 \text { oranında geleceklerini turizm sektöründe görmediklerini belirtmişlerdir. }\end{array}$ \\
\hline $\begin{array}{l}\text { Aksu ve Köksal } \\
(2005)\end{array}$ & $\begin{array}{l}\text { alışmaya katılan öğrencilerin genellikle olumsuz tutum içerisinde bulundukları ancak bunun } \\
\text { anında olumlu görüsslerde bulunanların da olduğu tespit edilmiştir. Olumlu fikir belirten } \\
\text { grencilerin yurtdışında sektör deneyimine sahip oldukları görülmüştür. }\end{array}$ \\
\hline & $\begin{array}{l}\text { Ortaöğretim ve Yükseköğretim düzeyinde turizm eğitimi alan öğrenciler turizm sektöründe } \\
\text { çalışmak istemekte ancak çalışma koşullarını olumsuz bulmaktadır. Geçmişte yapplan } \\
\text { çalışmaların aksine öğrencilerin turizmin iyi bir sosyal statü sağladığını düşündüğü görülmüştür. }\end{array}$ \\
\hline Erdinç (2012) & $\begin{array}{l}\text { Araştırmaya dâhil edilen öğrencilerin \%96'sının isteyerek turizm bölümü tercih ettiği ve bu } \\
\text { öğrencilerin \% \%0 kadarının bu kararlarından pişman olmadığı görülmüştür. Öğrencilerin turizm } \\
\text { bölümünü tercih etmesinin sebepleri sırasıyla statü/bireysel ilişkiler, endüstriyel bağlllık ve kişi } \\
\text { uyumu, ücret/yan ödeme, yükselme olarak tespit edilmiştir. }\end{array}$ \\
\hline & $\begin{array}{l}\text { ine göre gelecek kaygısının daha yüksek } \\
\text { c olduğu görülmüştür. Ögrencilerin sadece } \\
\text { r. }\end{array}$ \\
\hline & $\begin{array}{l}\text { raştırmaya katılan öğrencilerin büyük çoğunluğunun turizm meslek liselerinden mezun olduğu, } \\
\text { lüm tercihini gönüllü olarak yaptığ ve ilk } 5 \text { tercihlerinden birinin turizm bölümü olduğu } \\
\text { bülmüsstür. Öğrenciler turizm bölümünü seçme sebebi olarak turizmin geçerli bir meslek } \\
\text { uşunu ifade etmiştir. Öğrencilerin yüzde \%80'inden fazlası turizm alanında kariyer yapmak } \\
\text { tediğini belirtmiştir. }\end{array}$ \\
\hline $\begin{array}{l}\text { Koç, } \\
\text { Uluk } \\
\text { Topt }\end{array}$ & $\begin{array}{l}\text { Staj uygulamaları sonrası öğrencilerin \%18'inin turizm sektöründe çalışmak istemediği tespit } \\
\text { edilmiştir. }\end{array}$ \\
\hline $\begin{array}{l}\text { Güzel, Akdağ, } \\
\text { Güler ve Şener } \\
\text { (2014) }\end{array}$ & 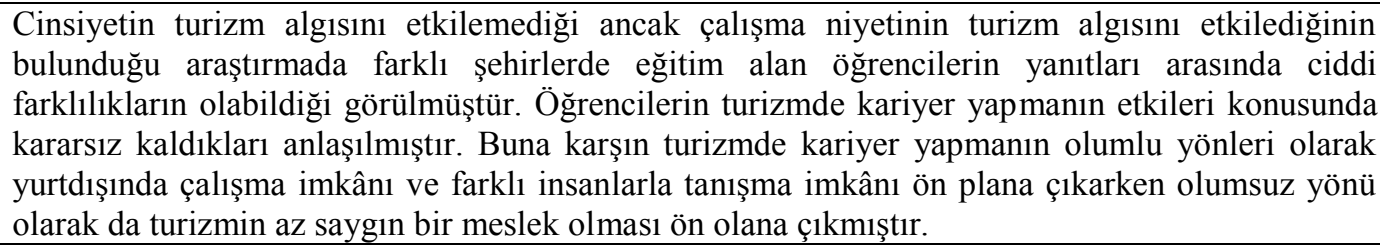 \\
\hline $\begin{array}{l}\text { Üzümcü, Alyakut } \\
\text { ve Günsel (2015) }\end{array}$ & $\begin{array}{l}\text { Araştırmaya katılan öğrencilerin \% } 023,2 \text { 'si aldıkları puana göre tercihte bulunurken bunu \% } 22,8 \\
\text { ile turizmin geçerli bir meslek oluşu seçeneği takip etmiştir. Öğrencilerin turizm sektöründen } \\
\text { beklentisi ise sırasıyla iş bulma ve çalışma koşulları, ücretler ve kariyer imkânı olarak } \\
\text { sıralanmıştır. Öğrencilerin büyük çoğunluğunun turizm sektöründe çalışmayı keyifli bulduğu ve } \\
\text { gelecekte de çalışmayı düşündükleri görülmüştür. }\end{array}$ \\
\hline Keleş (2017) & 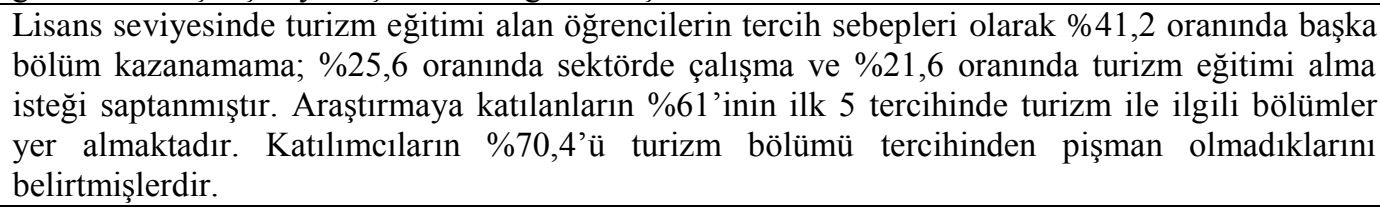 \\
\hline
\end{tabular}


Zengin ve Uzut (2017)
İstanbul'da bulunan vakıf üniversitelerinde lisans seviyesinde turizm eğitimi alan öğrencilerin tercihlerini etkileyen faktörleri sırasıyla saygınlık, bilgi ve istihdam, kampüs imkânları ve konum olarak tespit etmişlerdir. Ekonomik faktörlerin ise öğrencilerin tercihleri üzerinde çok etkili olmadığı görülmüştür.
Tablo 1. incelendiğinde her ne kadar turizm eğitimi alan öğrencilerin turizm sektörüne olan bakış açılarının zaman içerisinde iyileştiği görülse de olumsuz çalışma koşulları (Querrier, 1999), düzensiz çalışma saatleri, iş garantisi sorunu (Roney ve Öztin, 2007), düşük ücretler (Poulston, 2009), iş yükünün fazlalığı (Lo ve Lamm, 2005) ve sektörün doğasından kaynaklanan vardiyalı çalışma (Presbury vd., 2005) gibi nedenlerden dolayı sektör tecrübesi olan veya staj yapmış ögrencilerin (Koç vd., 2014) sektörde çalışmaya yönelik tutumlarının olumsuz olduğu görülmektedir. Bu olumsuz faktörler altında turizm ile ilgili bölümlerde eğitim alma isteğinde son y1llarda azalma görülmektedir. 2018 yılında yükseköğretim kurumlarında turizm bölümleri için açılan kontenjanların doluluk oranlarındaki azalma bu görüşü destekler niteliktedir (Bkz. Tablo 2).

Tablo 2. 2018 Yılı Turizm Bölümleri Kontenjanları ve Doluluk Oranları

\begin{tabular}{|l|c|c|c|}
\hline Program Türü & $\begin{array}{c}\text { Açılan } \\
\text { Kontenj } \\
\text { an }\end{array}$ & $\begin{array}{c}\text { Yerleşen } \\
\text { Öğrenci }\end{array}$ & $\begin{array}{c}\text { Doluluk } \\
\text { Oranı \% }\end{array}$ \\
\hline Ön Lisans & 23484 & 19619 & 83,5 \\
\hline Lisans & 11392 & 7534 & 66,1 \\
\hline Genel Toplam & 34876 & 27153 & 77,8 \\
\hline Bölüm \\
\hline Gastronomi & 10951 & 10355 & 94,6 \\
\hline Rekreasyon & 1014 & 911 & 89,8 \\
\hline Rehberlik & 3826 & 3033 & 79,3 \\
\hline $\begin{array}{l}\text { Turizm } \\
\text { İşletmeciliği }\end{array}$ & 19085 & 12854 & 67,4 \\
\hline
\end{tabular}

Kaynak: ÖSYM 2018-YKS turizm ön lisans ve lisans kontenjanları ve yerleştirme sonuçları istatistikleri ve raporu

Tablo 2'ye göre 2018 y1lında ön lisans ve lisans için açılan toplam kontenjanın \%22,2'si boş kalırken; aynı veri lisans bölümleri için \%37,9'dur. Turizm bölümlerinin kendi içindeki doluluk oranları incelendiğinde ise açılan kontenjanları en fazla dolduran bölümler sirasıyla gastronomi, rekreasyon, rehberlik ve turizm işletmeciliğidir. $\mathrm{Bu}$ çalışmanın amacı turizm bölümleri arasındaki kontenjan doluluk oranlarında görülen farkl1lıklar temel alınarak, Türkiye'de lisans düzeyinde turizm eğitimi alan öğrencilerin, turizm ile ilgili tercihlerini etkileyen faktörleri tespit etmektir.

\section{YÖNTEM}

\section{Araştırmanın Hipotezleri}

Araştırmanın temel amacı turizm lisans öğrencilerinin turizm ile ilgili bölümleri tercih nedenlerini tespit etmektir. Araştırmada belirlenen alt hipotezler ise şunlardır:

$\mathrm{H}_{1}$ : Araştırmaya katılan öğrencilerin cinsiyetlerine göre turizmle ilgili bölümleri tercih nedenleri arasında bir fark vardır.

$\mathrm{H}_{2}$ : Araştırmaya katılan öğrencilerin ortaöğretim durumlarına göre turizmle ilgili bölümleri tercih nedenleri arasında bir fark vardır.

$\mathrm{H}_{3}$ : Araştırmaya katılan öğrencilerin YKS'deki tercih sirası ile tercih nedenleri arasında bir fark vardir.

\section{Evren ve Örneklem}

Araştırmanın evrenini, Türkiye'de turizm lisans eğitimi alan yeni kayıtlı öğrenciler oluşturmaktadır. Evrenin tamamına ulaşmak zaman ve maliyet açısından zor olduğundan, 2018 y1lı kontenjan doluluk oranları ve kolay ulaşılabilirlik dikkate alınarak örnekleme karar verilmiştir. Araştırmanın örneklemini, Eskişehir Osmangazi Üniversitesi, Anadolu Üniversitesi, Gazi Üniversitesi ve Adnan Menderes Üniversitesi'nin lisans düzeyinde eğitim veren farklı bölümlerde (turizm işletmeciliği, konaklama işletmeciliği, gastronomi, turizm rehberliği) turizm eğitimi alan 1. sınıf (I. ve II. öğretim) öğrenciler oluşturmaktadır.

\section{Veri Toplama Aracı}

Araştırmada nicel araştırma yönteminden yararlanılarak, veriler anket tekniği ile toplanmış, toplamda 409 katılımcıdan veri elde edilmiştir. Eksik ve hatalı kodlanmış anketler çıkarıldıktan sonra 406 anket analiz edilmiştir. Saha araştırması 01.11.2018-10.12.2018 tarihleri arasında Eskişehir, Ankara ve Kuşadası illerinde gerçekleştirilmiştir. Veri toplama araci olarak anket formundan yararlanılmıştır. Anket formu iki bölümden 
oluşmaktadır. Birinci bölüm katılımcıların demografik bilgilerini ölçmeye yöneliktir. Demografik sorular hazırlanırken benzer çalışmaların [Duman, Tepeci ve Unur (2006); Köşker ve Unur (2017)] anketleri incelenerek sorular derlenmiştir. İkinci bölüm ise öğrencilerin turizm ile ilgili bölümleri tercih nedenlerine yönelik 28 sorudan oluşmaktadır. Ölçekte yer alan "kesinlikle kat1liyorum" (5), "kat1lyyorum" (4), "kararsızım" (3), "katılmıyorum" (2), "kesinlikle katılıyorum" (1) değerini ifade etmektedir. Söz konusu ölçek daha önce geçerlik ve güvenirlik analizleri yapılmış olan Erdinç ve Kahraman'ın (2012) çalışmasından alınarak kullanılmıştır. Veriler SPSS 22. Programı kullanılarak analiz edilmiştir. Öncelikle ölçeğin yap1 geçerliği için açıklayıcı faktör analizi, güvenirliği için Cronbach's Alpha uygulanmıştır.

\section{BULGULAR}

Tablo 3'te katılımcıların demografik özelliklerine ilişkin bulgular yer almaktadır. Araştırmaya katılan 406 lisans turizm öğrencisinin \%58,5'i erkeklerden, \%41,5'i kadınlardan oluşmaktadır. Öğrencilerin \%83,7'si 17-21 yaş; \%14,1'i 22-26 yaş; \%2,2'si 27-31 yaş aralığındadır. Katılımcıların \%58,7'si Anadolu Lisesi mezunu, \%12,4'ü Turizm Meslek Lisesi, \%2'si İmam Hatip Lisesi, \%27 oranında diğer lise türünden mezundur.

Tablo 3'e göre katılımcıların okudukları bölüme ilişkin bulgular görülmektedir. Öğrencilerin \%77,6's1 I. Öğretim; \%22,4'ü II. Öğretim okumaktadırlar. Katılımcıların tercih sırasina bakıldığında, yarısından fazlasının $(\% 66,5)$ ilk 5 tercihinden birinin turizmle ilgili bölümler olduğu anlaşılmaktadır. Tercih sırası 6-10 aralığında olanların oran $\% 18,2$; tercih siras 1 11-16 arasında olan katılımc1 oranı $\% 10,1$ ve 16 ve üzeri tercih yapanların oranı ise $\% 5,2$ 'dir.

Turizm sektörü hakkında bilgi sahibi olduğunu belirten katılımcıların oran1 \%57,9 iken; turizm sektörü hakkında bilgi sahibi olmayanların oranı $\% 42,1$ olarak tespit edilmiştir.

Aynı tabloya göre katılımcıların üniversite tercih nedenleri söz konusu olduğunda \%44,8'lik oranla ilk sirada üniversitenin bulunduğu şehir yer almıştır. İkinci sırada Üniversitenin imajı $\% 26,8$ 'lik oranla bir diğer üniversite tercih nedenini oluşturmaktadır. Üniversite tercih nedenlerinden bir diğeri $\% 10,8$ 'lik oranla yakın çevre tavsiyesi iken katılımcıların \%17,5'i diğer nedenlerle okudukları üniversiteyi tercih ettiklerini belirtmişlerdir. Bu diğer nedenler $(\% 17,5)$ arasında ailenin yaşadığ 1 şehir, ailevi nedenler, parasal etmenler gibi birçok neden sayılabilir. Oranlara bakıldığında öğrencilerin yaklaşık yarısının üniversite tercihinde üniversitenin bulunduğu şehir faktörünün önemli olduğu görülmektedir. Söz konusu üniversiteler coğrafi konum itibariyle hem de kontenjan bakımından 2018 yılında doluluk oranları yüksek olan üniversitelerdir.

Katılımcıların $\% 35$ 'i Turizm İşletmeciliği; \%29,6's1 Turizm Rehberliği; \%21,9'u Gastronomi ve Mutfak Sanatları; \%6,9'u Yiyecek İçecek İşletmeciliği; \%4,7'si Konaklama İşletmeciliği ve $\% 2$ 'si Seyahat İşletmeciliği bölümü öğrencilerinden oluşmaktadır.

Tablo 3. Demografik Bulgular

\begin{tabular}{|c|c|c|c|c|c|}
\hline & Frekans & $(\%)$ & & Frekans & $(\%)$ \\
\hline \multicolumn{3}{|l|}{ Cinsiyet } & \multicolumn{3}{|l|}{ Bölüm } \\
\hline Kadın & 168 & 41,4 & Turizm İşletmeciliği & 142 & 35 \\
\hline Erkek & 237 & 58,4 & Turizm Rehberliği & 120 & 29,6 \\
\hline Toplam & 405 & 99,8 & Gastronomi & 89 & 21,9 \\
\hline \multicolumn{3}{|l|}{ Yaş } & Yiyecek-içecek İşletmeciliği & 28 & 6,9 \\
\hline $17-21$ & 339 & 83,5 & Konaklama İşletmeciliği & 19 & 4,7 \\
\hline $22-26$ & 57 & 14,0 & Seyahat İşletmeciliği & 8 & 2 \\
\hline $27-31$ & 9 & 2,2 & Toplam & 406 & 100 \\
\hline Toplam & 405 & 99,8 & \multicolumn{3}{|c|}{ Daha Önce Turizm Eğitimi Alma } \\
\hline \multicolumn{3}{|l|}{ Ortaöğretim Kurumu } & Evet & 66 & 16,3 \\
\hline İmam Hatip Lisesi & 8 & 2,0 & Hayır & 340 & 83,7 \\
\hline Anadolu Lisesi & 237 & 58,4 & Toplam & 406 & 100 \\
\hline Turizm Meslek Lisesi & 50 & 12,3 & \multicolumn{3}{|l|}{ Ailede Eğitim Alan var mı? } \\
\hline Diğer & 109 & 26,8 & Evet & 72 & 17,7 \\
\hline Toplam & 404 & 99,5 & Hayır & 334 & 82,3 \\
\hline Sinıfinız & & & Toplam & 406 & 100 \\
\hline
\end{tabular}




\begin{tabular}{|c|c|c|c|c|c|}
\hline I. Öğretim & 315 & 77,6 & \multicolumn{3}{|l|}{ Bölümü İsteyerek mi seçtiniz? } \\
\hline II. Öğretim & 91 & 22,4 & Evet & 274 & 67,5 \\
\hline Toplam & 406 & 100 & Hayır & 54 & 13,3 \\
\hline \multicolumn{3}{|l|}{ Tercih Siranız } & Kararsız & 78 & 19,2 \\
\hline $1-5$ & 270 & 66,5 & Toplam & 406 & 100 \\
\hline $6-10$ & 74 & 18,2 & \multicolumn{3}{|l|}{ Bölümü Tercih Nedeniniz } \\
\hline $11-15$ & 41 & 10,1 & Sektörde çalışma isteği & 135 & 33,3 \\
\hline 16 ve üzeri & 21 & 5,2 & Turizm eğitimi alma isteği & 90 & 22,2 \\
\hline \multirow{2}{*}{ Toplam } & \multirow{2}{*}{406} & \multirow{2}{*}{100} & Günümüzde geçerli bir meslek & 79 & 19,5 \\
\hline & & & Başka bölüm kazanamama & 62 & 15,3 \\
\hline \multicolumn{3}{|c|}{ Sektör hakkında bilgi sahibi olma } & Yakın çevre tavsiyesi & 26 & 6,4 \\
\hline Evet & 235 & 57,9 & Üniversite mezunu olmak & 22 & 5,4 \\
\hline Hayır & 171 & 42,1 & Diğer & 52 & 12,8 \\
\hline Toplam & 406 & 100 & \multirow{2}{*}{ Araştırmaya katılan üniversiteler } & & \\
\hline \multicolumn{3}{|l|}{ Üniversite tercih nedeni } & & & \\
\hline Üniversitenin bulunduğu şehir & 182 & 44,8 & Adnan Menderes Üniversitesi & 142 & 35 \\
\hline Üniversitenin imaj1 & 109 & 26,8 & Osmangazi Üniversitesi & 109 & 26,8 \\
\hline Yakın çevre tavsiyesi & 44 & 10,8 & Anadolu Üniversitesi & 116 & 28,6 \\
\hline Diğer & 71 & 17,5 & Gazi Üniversitesi & 39 & 9,6 \\
\hline Toplam & 406 & 100 & Toplam & 406 & 100 \\
\hline
\end{tabular}

Yukarıdaki tabloya göre katılımcıların \%83,7'si daha önce turizm eğitimi almamıştır, ancak $\% 16,3$ 'lük bir kesim ise daha önce turizm eğitimi almıştır. Benzer şekilde ailelerinde turizm eğitimi almamış olanların oranı \%82,3 iken; ailesinde turizm eğitimi almış olanların oranı \%17,7'dir. Buna göre, öğrencilerin yarıdan fazlasının daha önce turizm eğitimi almadıklarını ve ailelerinde turizm eğitimi alanların oranının düşük olduğunu söyleyebiliriz.

Öğrencilerin tercih ettikleri bölüme göre, $\% 67,5$ 'inin bölüm tercihini isteyerek gerçekleştirdiği, \%13,3'ünün istemeyerek tercihte bulunduğu ve \%19,2'sinin bu konuda kararsiz olduğu görülmektedir.

Katılımcıların turizm ile ilgili bölümleri tercih etme nedenlerine bakıldığında ise; ilk sirada \%33,3'lük oranla sektörde çalışma isteği gelmektedir. Bunun ardından \%22,2'lik bir oranla turizm eğitimi alma isteği gelmektedir. Katılımcıların turizmi günümüzde geçerli bir meslek olarak görüyor olmaları \%19,5'lik oranla bir diğer tercih sebebini oluşturmaktadır. Başka bir bölüme puanın yetmemesi de \%15,3'lik bir oranla bir tercih nedeni olarak görülmektedir. Öğrencilerin \%6,4'ü yakın çevre tavsiyesi, \%5,4'ü ise üniversite mezunu olmak için bölüm tercihinde bulunduklarını belirtirken; \%12,8'lik bir kesim ise bunların dışında nedenlerle tercihte bulunduklarını belirtmiştir.

Araştırmaya katılan üniversitelerin oranları sirasiyla \%35'i Adnan Menderes Üniversitesi, \%28,6's1 Anadolu Üniversitesi, \%26,8'i Osmangazi Üniversitesi ve \%9,6's1 Gazi Üniversitesi'dir.

Tablo 4. Turizm Tercih Nedenlerine Yönelik Faktör Analizi

\begin{tabular}{|c|c|c|c|}
\hline Faktörler & $\begin{array}{l}\text { Faktör } \\
\text { Yükleri }\end{array}$ & Açıklanan Varyans & Cronbach's Alpha \\
\hline \multicolumn{4}{|c|}{ Bireysel İlişkiler } \\
\hline Yeni ve farklı yerler görmek istiyorum. &, 832 & \multirow{7}{*}{33,829} & \multirow{7}{*}{,867 } \\
\hline Farklı kültürleri ve insanları tanımak istiyorum. & ,783 & & \\
\hline Farklı deneyimler elde etmek istiyorum. & 674 & & \\
\hline Daha fazla seyahat etmek istiyorum. & 697 & & \\
\hline Sürekli olarak sosyal güvenceye sahip olmak istiyorum. & 685 & & \\
\hline Hoş bir ortamda çalışmak istiyorum. & 761 & & \\
\hline Mutlu olan insanlarla bir arada olmak istiyorum. & 669 & & \\
\hline
\end{tabular}




\begin{tabular}{|c|c|c|c|}
\hline \multicolumn{4}{|c|}{ Sosval Statü } \\
\hline $\begin{array}{l}\text { Turizmi daha çok arkadaş edinebildiğim bir iş olarak } \\
\text { görüyorum. }\end{array}$ & ,658 & \multirow{6}{*}{10,302} & \multirow{6}{*}{,792 } \\
\hline İnsanlarla sürekli iletişim içinde olmaktan hoşlanıyorum. & ,532 & & \\
\hline $\begin{array}{l}\text { Turizmin sosyal hayatıma önemli katkılar sağlayacağına } \\
\text { inanıyorum. }\end{array}$ & ,694 & & \\
\hline $\begin{array}{l}\text { Bu sektörde kendimi daha bağımsız hissedeceğime } \\
\text { inanıyorum. }\end{array}$ & ,749 & & \\
\hline Çalışma koşullarının bana uygun olduğunu düşünüyorum. & 684 & & \\
\hline Gelecekte bu sektörde kendi işimi kurmak istiyorum. &, 614 & & \\
\hline \multicolumn{4}{|c|}{ Endüstriyel Bağlılık/ Kişi-Turizm Sektörü Uyumu } \\
\hline $\begin{array}{l}\text { Yeteneklerimi en iyi turizmde kullanabileceğime } \\
\text { inanyyorum. }\end{array}$ & ,776 & \multirow{5}{*}{5,109} & \multirow{5}{*}{,717 } \\
\hline $\begin{array}{l}\text { Turizmin toplum tarafindan prestijli bir sektör olarak } \\
\text { kabul edildiğini düşünüyorum }\end{array}$ & ,625 & & \\
\hline $\begin{array}{l}\text { Gelecekte de bu alanda öğrenimime devam etmek } \\
\text { istiyorum. }\end{array}$ & ,806 & & \\
\hline Daha fazla bilgiye ulaşabileceğime inanıyorum. & ,383 & & \\
\hline Aldığım eğitimle ilgili bir iş sahibi olmak istiyorum. &, 725 & & \\
\hline \multicolumn{4}{|c|}{ Ücret/Yan Ödeme } \\
\hline Turizmde çok iyi iş firsatları olduğunu düşünüyorum. &, 792 & \multirow{5}{*}{4,070} & \multirow{5}{*}{,740 } \\
\hline Turizmi yüksek kazançlı bir sektör olarak görüyorum. & ,704 & & \\
\hline Daha iyi bir hayat standardı sağlamak istiyorum. & ,714 & & \\
\hline Uygun bir gelire sahip olmak istiyorum. & ,691 & & \\
\hline Kısa zamanda çok kazanabileceğimi düşünüyorum. & ,608 & & \\
\hline \multicolumn{4}{|c|}{ Yükselme Olanakları } \\
\hline $\begin{array}{l}\text { Turizmde çalışmanın diğer sektörlere göre daha kolay } \\
\text { olduğunu düşünoryorum. }\end{array}$ &, 580 & \multirow{4}{*}{3,833} & \multirow{4}{*}{, 552} \\
\hline $\begin{array}{l}\text { Turizm sayesinde birçok ünlü kişi ile tanışabileceğimi } \\
\text { düşünüyorum. }\end{array}$ & ,607 & & \\
\hline $\begin{array}{l}\text { Turizmde yükselme olanaklarının diğer sektörlere göre } \\
\text { daha kolay olduğunu düșünüyorum. }\end{array}$ & ,791 & & \\
\hline Turizmin sahip olduğu imaj bana çok çekici geliyor. & ,637 & & \\
\hline $\begin{array}{r}K M O(\text { Kaiser-Meyer-Olkin) } \\
\text { Bartlett's Testi ki-kare } \\
p\end{array}$ & $\begin{array}{r}0,916 \\
4458,470 \\
0,000\end{array}$ & 57,143 & ,899 \\
\hline
\end{tabular}

Tablo 4'te ölçeğin yapı geçerliğine dair varimax rotasyonu gerçekleştirilerek yapılan faktör analizi, Cronbach's Alpha değerleri verilmiştir. Buna göre 27 soruya ilişkin ölçeğin 5 boyutlu olduğu görülmektedir. 5 faktör, toplam varyansın $\% 57$, 143'ünü açıklamaktadır. Birinci faktör (Bireysel ilişkiler) toplam varyansın \% 33,829'unu, ikinci faktör (Sosyal statü) toplam varyansin \%10,302'sini, üçüncü faktör (Endüstriyel Băglllık) Kişi-Sektör Uyumu) toplam varyansın \%5,109'unu, dördüncü faktör (Ücret/Yan ödeme) toplam varyansin \%4,070'ini ve beşinci faktör (Yükselme) ise toplam varyansın \%3,833'ünü açıklamaktadır. Her bir soruya ilişkin faktör yükleri Tablo 4'te görülmektedir. Üçüncü faktör altında yer alan ifadenin faktör yükü düşük $(<.40)$ olduğundan dolayı ölçekten çıkartılmıştır. KMO örnekleme yeterliliğinin kabul edilebilir alt sınırı 0,50'dir (Durmuş, Yurtkoru ve Çinko, 2018:80). KaiserMeyer-Olkin örneklem yeterliliği, 0,916 ( $p<.000)$ verinin faktör analizine uygunluğunun mükemmel olduğunu göstermektedir. Faktör yükleri 0,50'nin üzerinde olduğundan kabul edilebilir düzeydedir. Güvenirlik analizi için Cronbach's Alpha değerine bakılmıştır. Ölçeğin genel güvenirliği Tablo 4'e göre, $\alpha=0,899$ olarak hesaplanmıştır. Bu durumda, ölçeğin yüksek derecede güvenilir bir ölçek $(0,80<\alpha<1)$ olduğu (Ural ve Kılıç, 2013) söylenebilir. Erdinç ve Kahraman (2012) tarafindan Akdeniz Üniversitesi Turizm İşletmeciliği ve Otelcilik Yüksekokulu birinci sınıf öğrencileri özelinde yapılan çalışmada dört faktör, 
bizim çalışmamızda ise beş faktör altında toplanmıştır. $\mathrm{Bu}$ farklılığı, araştırmaya katılan farklı üniversiteler ve bölümlerden oluşan ögrencilerin farklı beklentilere sahip olmasına bağlayabiliriz.

Katılımcıların Demografik Özellikleri İle Turizm İle İlgili Bölümleri Tercih Nedenleri Arasındaki İlişkiye Yönelik Bulgular

Cinsiyetin, tercih nedenleri üzerinde anlamlı bir etkisinin olup olmadığının belirlenmesi için uygulanan bağımsız örneklem t-testi sonucuna göre, kadınların turizmle ilgili bölümleri tercih nedenleri bireysel ilişki faktörü için (varyanslar homojen, $\mathrm{p}=, 419, \mathrm{t}=1,064 \mathrm{p}=$,288) erkeklere göre anlamlı bir farklılığa sahip değildir. Lisans öğrencilerinin sosyal statü $(\mathrm{t}=1,341, \mathrm{p}=, 181)$, kişiturizm uyumu $(\mathrm{t}=1,261, \mathrm{p}=, 208)$, ücret ve yan ödemeler $(\mathrm{t}=1,441, \mathrm{p}=, 150)$ ve yükselme olanakları $(t=1,729, \quad p=, 085) \quad$ boyutlarındaki görüşleri arasında anlamlı bir farklı1ık olmadığı görülmüştür $(\mathrm{p}>0,05)$. Yani, araştırmaya katılan lisans öğrencilerinin cinsiyetlerine göre turizmle ilgili bölümleri tercih nedenleri arasında anlamı bir fark yoktur. $\mathrm{Bu}$ nedenle $\mathrm{H}_{1}$ hipotezi desteklenmemiştir. Türker, Uçar ve Ateş'in (2016) çalışmalarında da turizm öğrencilerinin cinsiyetlerine göre turizmi algılamaları arasında bir farklılık bulunamamıştır. Kozak ve Kızılırmak'ın (2001) çalışmalarında da turizm sektörüne karşı olan tutumun cinsiyete göre farklılık göstermediği tespit edilmiştir.

Tablo 5. Cinsiyete Göre Bağımsız Örneklem T-Testi

\begin{tabular}{|l|c|c|c|}
\multicolumn{1}{|c}{ Sonuçları } \\
$\begin{array}{c}\text { Faktör } \\
\text { Boyutları }\end{array}$ & $\begin{array}{c}\text { Serbestlik } \\
\text { derecesi }\end{array}$ & $\mathbf{t}$ & $\mathbf{p}$ \\
\hline Bireysel ilişki & 389 & 1,064 &, 288 \\
\hline Sosyal statü & 392 & 1,341 &, 181 \\
\hline $\begin{array}{l}\text { Kişi-turizm } \\
\text { uyumu }\end{array}$ & 393 & 1,261 &, 208 \\
\hline $\begin{array}{l}\text { Ücret ve yan } \\
\text { ödemeler }\end{array}$ & 391 & 1,441 &, 150 \\
\hline $\begin{array}{l}\text { Yükselme } \\
\text { olanakları }\end{array}$ & 395 & 1,729 &, 085 \\
\hline
\end{tabular}

Öğrencilerin mezun oldukları öğretim kurumlarına göre turizmle ilgili bölümleri tercih nedenlerine yönelik tek yönlü varyans (Anova) analizi yapılmıştır. Tek yönlü Varyans analizi yapabilmek için ön koşulu sağlamak adına Levene testi yapılmıştır. Bireysel ilişki faktörü $(p=, 018) p$ değeri 0,05 'den küçük olduğu için varyansların eşitliği kabul edilmemiştir. $\mathrm{Bu}$ nedenle varyans analizine dâhil edilmemiştir. Sosyal statü faktörü $(\mathrm{p}=$,937), kişi-turizm uyumu $(\mathrm{p}=, 169)$, ücret ve yan ödemeler $(p=, 508)$, yükselme olanakları $(p=, 764)$ boyutlarının $\mathrm{p}$ değeri 0,05 'den büyük olduğundan varyansların eşitliği kabul edilmiştir. Öğrencilerin sosyal statü $F$ değeri 1,103 ve buna karş1lık gelen $p$ değeri $0,348 \quad(p>0,05)$ bulunmuştur. Kişi-turizm uyumu boyutunda $\mathrm{F}$ değeri 3,520 ve buna karş111k gelen $\mathrm{p}$ değeri ise 0,015 olup 0,05 'den küçüktür. Ücret ve yan ödemeler boyutunda F değeri 2,490 ve $\mathrm{p}$ değeri ise 0,060 bulunmuştur. Yükselme olanakları boyutunda $\mathrm{F}$ değeri 1,976 olup buna karş1lık gelen $p$ değeri 0,117 olup 0,05 'den büyüktür. Dolayısıyla araştırmaya katılan lisans öğrencilerinin mezun olunan lise türüne (Anadolu lisesi, turizm lisesi vb) göre turizmle ilgili bölümleri tercih nedenleri sadece kişi-turizm uyumu $\quad(\mathrm{p}<0,05) \quad$ boyutunda farkl11.k göstermektedir. $\mathrm{H}_{2} \quad$ hipotezi kismen desteklenmiştir.

Tablo 6. Mezun Olunan Lise Türüne Göre Tek Yönlü Varyans Analizi Sonuçları

\begin{tabular}{|l|c|c|c|}
\hline \multicolumn{1}{|c|}{$\begin{array}{c}\text { Faktör } \\
\text { Boyutları }\end{array}$} & $\begin{array}{c}\text { Serbestlik } \\
\text { derecesi }\end{array}$ & F & p \\
\hline Sosyal statü & 389 & 1,103 &, 348 \\
\hline $\begin{array}{l}\text { Kişi-turizm } \\
\text { uyumu }\end{array}$ & 390 & 3,520 &, 015 \\
\hline $\begin{array}{l}\text { Ücret ve yan } \\
\text { ödemeler }\end{array}$ & 388 & 2,490 &, 060 \\
\hline $\begin{array}{l}\text { Yükselme } \\
\text { olanakları }\end{array}$ & 392 & 1,976 &, 117 \\
\hline
\end{tabular}

Araştırmaya katılan öğrencilerin YKS'deki tercih sırası ile turizmle ilgili bölümleri tercih nedenlerine yönelik tek yönlü varyans analizi (Anova) yapılmıştır. Öncelikle Levene testinin sonucuna göre varyansların eşitliği kabul edilmiştir ( $p$ değeri $>0,05)$. Buna göre sosyal statü $(p=, 249)$, kişi-turizm uyumu $(p=, 312)$, ücret $(p=, 055)$ ve yükselme olanakları $(\mathrm{p}=, 213)$ boyutlarının $\mathrm{p}$ değeri 0,05 'den büyük olduğundan varyansların eşitliği kabul edilmiştir. Bireysel ilişki $(\mathrm{p}=0,004) \mathrm{p}$ değeri 0,05 'den küçük olduğundan varyans eşitliği kabul edilmemiştir. Tek yönlü varyans analizinin sosyal statü faktörü için $\mathrm{F}$ değeri 1,542 ve buna karşı11k gelen $\mathrm{p}$ değeri 0,203 bulunmuştur. $\mathrm{Bu}$ sonuç lisans öğrencileri için sosyal statünün turizmle ilgili 
bölümleri tercih etmelerinde bir fark olmadığını gösterir. Kişi-turizm uyumu faktörü için $F$ değeri 2,735 ve buna karşıllk gelen $p$ değeri 0,043 olup $p$ değeri 0,05 'den küçüktür. $\mathrm{Bu}$ sonuç lisans öğrencilerinin YKS'deki tercih sırasının kişiturizm uyumu boyutunda farklılık olduğunu göstermektedir. Ücret faktörü için F değeri 1,739 ve buna karşıllk gelen $p$ değeri 0,158 olup $p$ değeri 0,05 'den büyüktür. $\mathrm{Bu}$ sonuç öğrencilerin YKS'deki tercih sırasının ücret faktörü için turizmle ilgili bölümleri tercih nedenlerine göre farklı olmadığını gösterir. Yükselme olanakları faktörü için $F$ değeri 0,570 ve buna karş1lık gelen $p$ değeri 0,635 olup $p$ değeri 0,05 'den büyüktür. Dolayısıyla lisans öğrencilerinin YKS'deki tercih sıralarının sadece kişi-turizm uyumu boyutunda farklılık olduğunu göstermektedir. $\mathrm{Bu}$ nedenle $\mathrm{H}_{3}$ hipotezi kısmen desteklenmiştir.

Tablo 7. Tercih Sırasına Göre Tek Yönlü Varyans Analizi Sonuçları

\begin{tabular}{|l|c|c|c|}
\hline \multicolumn{1}{|c|}{$\begin{array}{c}\text { Faktör } \\
\text { Boyutları }\end{array}$} & $\begin{array}{c}\text { Serbestlik } \\
\text { derecesi }\end{array}$ & $\mathbf{F}$ & $\mathbf{p}$ \\
\hline Sosyal statü & 389 & 1,542 &, 203 \\
\hline $\begin{array}{l}\text { Kişi-turizm } \\
\text { uyumu }\end{array}$ & 390 & 2,735 &, 043 \\
\hline $\begin{array}{l}\text { Ücret ve yan } \\
\text { ödemeler }\end{array}$ & 388 & 1,739 &, 158 \\
\hline $\begin{array}{l}\text { Yükselme } \\
\text { olanakları }\end{array}$ & 392 & 0,570 &, 635 \\
\hline
\end{tabular}

\section{SONUÇ}

$\mathrm{Bu}$ çalışmada YKS 2018'de turizmle ilgili bölümleri tercih eden öğrencilerin bölüm ve üniversite tercihlerini etkileyen faktörlerin neler olduğu açığa çıkarılmaya çalışılmıştır. $\mathrm{Bu}$ kapsamda öğrencilerin turizm bölümlerini tercih nedenleri incelendiğinde turizm sektöründe çalışma isteğinin $(\% 33,3)$ ilk sırada geldiği görülmektedir. Bu sonuç öğrencilerin sektörü iyi tanımamaları ve staj deneyimlerinin henüz oluşmamasına bağlanabilir. Köşker ve Unur (2017), Koç ve diğerleri (2014) tarafından yapılan çalışmalar, turizm eğitimi alan öğrencilerin sektörü tanımaya, tecrübe kazanmaya başladıkça sektörde çalışma isteklerinde azalma olduğunu göstermektedir. Aynı şekilde TUADER Başkanı Prof. Dr. Muharrem Tuna günümüzde çalışma koşullarının ağır olması, ücretlerin düşük olması, diplomaların değer görmemesi gibi etkenlerden dolayı, turizm mezunlarının sadece \%30'unun sektörde çalışmayı tercih etmektedirler (www.turkiyeturizm.com). Bu oran çıkan sonucu destekler niteliktedir.

Kat1lımciların \%83,7'sinin daha önce turizm eğitimi almadığı da ulaşılan bir diğer bulgudur. Tercih nedenlerinden birisi olan başka bölüm kazanamamaktan kaynaklı olarak turizm bölümü tercih oranı ise \%15,3'tür. Keleş (2017) tarafindan yapılan araştırmada ise bu oran $\% 41,2$ olarak belirlenmiştir. $\mathrm{Bu}$ durum her iki çalışmanın örneklem sahasının birbirinden farklı olması sebebiyle ortaya çıkmış olabilir.

Araştırmaya katılan öğrencilerin üniversite tercihi söz konusu olduğunda ise tercihlerini etkileyen ilk unsurun üniversitenin bulunduğu şehir olduğu görülmüştür. Öyle ki üniversitenin bulunduğu şehrin bölüm tercihleri üzerinde etkili olduğunu söyleyen öğrencilerin oran1 \%44,8 iken, üniversite imajının bölüm tercihi üzerinde etkili olduğunu ifade eden öğrencilerin oranı \%26,8'dir. Bu durumun sebebi söz konusu üniversitelerin bulunduğu şehirlerde yüksek hızlı tren bağlantılarının olması, şehir merkezinde yer almaları sebebiyle ulaşımın kolay olması, üniversite şehri olarak (örn, Eskişehir) bilinmesi gibi etmenler siralanabilir.

Demografik özellikler değerlendirildiğine ise cinsiyete göre, turizm bölümlerinin kadınlara $(\% 41,4)$ oranla erkekler $(\% 58,4)$ tarafindan daha fazla tercih edildiği görülmüştür. Ancak sadece birinci öğretimler değerlendirmeye alındığında oranların birbirine daha yakın olduğu görülmektedir (Erkek: \%54; Kadın: \%46).

Çalışmadan elde edilen bir diğer sonuç turizm bölümü tercihinde bulunan öğrencilerin yalnızca \%12,3'lük bir bölümünün turizm meslek lisesi mezunu olmasıdır. Bu durumda turizmin diğer lise türlerinin öğrencileri arasında da rağbet gördüğü söylenebilir. Öğrencilerin \%57,9'luk bir çoğunluğunun turizm hakkında bilgi sahibi olarak, $\% 67,5$ 'inin ise turizm mesleğini isteyerek seçtikleri görülmüştür. Erdinç ve Kahraman (2012) tarafindan yapılan araştırma bu oran \%96 iken; Köşker ve Unur (2017) tarafindan yapılan araştırmada bu oran \%72,4 olarak belirlenmiştir. Yıllar geçtikçe oranda azalma görülmekle birlikte bu veri öğrencilerin önemli bir kısmının turizm mesleğini istekli olarak tercih ettikleri şeklinde yorumlanabilir. 
$\mathrm{Bu}$ araştırma 2018 YKS tercih sonuçlarına göre doluluk oranları yüksek olan üniversitelerin ilgili bölümlerinde gerçekleştirilmiştir. Gelecek araştırmalar, doluluk oranları düşük olan üniversitelerle yüksek olan üniversiteler arasında bir karşılaştırma yapabilirler.

\section{KAYNAKÇA}

Aksu, A. ve Köksal, C.D. (2005). Perceptions and Attitudes of Tourism Students in Turkey, International Journal of Contemporary Hospitality Management, 17(5), 436-447.

Avcıkurt, C., Deveci, B. ve Türkmen, S. (2012). Balıkesir Üniversitesi Turizm İşletmeciliği ve Otelcilik Yüksekokulu (BTIYO) mezunlarının turizm sektöründeki istihdam profili, Turizm eğitimi konferans-workshop kitabı içinde, Turizm Eğitimi Konferansl, Ankara, 109-119.

Baltacı, F., Üngüren, E., Avsallı, H., Demirel, O.N. (2012). Turizm eğitimi alan öğrencilerin eğitim memnuniyetlerinin ve geleceğe yönelik bakış açıların belirlemesine yönelik bir araştırma. Uluslararası Alanya İşletme Fakültesi Dergisi, 4(1), 17-25.

Duman, T., Tepeci, M., Unur, K. (2006). Mersin'de yükseköğretim ve orta öğretim düzeyinde turizm eğitimi almakta olan öğrencilerin sektörün çalışma koşullarını algılamaları ve sektörde çalışma isteklerinin karşılaştırmalı analizi. Anatolia: Turizm Araştırmaları Dergisi, 17(1)5169.

Durmuş, B., Yurtkoru, E. S. ve Çinko, M. (2018). Sosyal bilimlerde SPSS'le veri analizi. Beta Basım Yayım: İstanbul.

Dinçer, İ.F, Akova, O., Kaya, F. (2013). Meslek yüksekokulu turizm ve otel işletmeciliği programı öğrencilerinin kariyer planlaması üzerine bir araştırma: İstanbul Üniversitesi ve Gümüşhane Üniversitesi örneği.

Erdinç, S.B. (2012). Determining of college students' trends about tourism sector: A case study at Akdeniz University. Procedia - Social and Behavioral Sciences, 47, 1573-1577.

Erdinç, S.B., ve Kahraman, S. (2012). Turizm mesleğini seçme nedenlerinin incelenmesi. VI. Lisansüstü Turizm Öğrencileri Araştırma Kongresi, 229-237.

Güzel, T., Akdağ, G., Güler, O. Şener, S. (2014). Turizm eğitimi alan öğrencilerin turizmde kariyer algılamaları: Çanakkale, Mersin ve Kıbrıs'ta bir araştırma. 3.Doğu Akdeniz Sempozyumu, ss:176187 , Mersin.

Karaman, A., Metin, A.E., Güven, Ş. (2017) Ormancılık ve orman ürünleri programını tercih eden öğrencilerin gerekçelerinin ve kariyer planlarının araştırılması: Uşak Üniversitesi örneği. İnsan Ve Toplum Bilimleri Araştırmaları Dergisi, 6(2), 859-872.

Keleş, Y. (2017). Neden turizm eğitimi? Lisans düzeyinde turizm öğrencilerine yönelik bir araştırma. 18. Ulusal Turizm Kongresi, 143-150

Koç, E., Yumuşak, S., Ulukoy, M., Kılıç, R., Toptaş, A. (2014). Are internship programs encouraging or discouraging? - A view point of tourism and hospitality students in Turkey. Journal of Hospitality, Leisure, Sport \& Tourism Education 15, 135-142.

Kozak, M. ve Kizılırmak, İ. (2001). Türkiye'de meslek yüksekokulu turizm otelcilik programı öğrencilerinin turizm sektörüne yönelik tutumlarının demografik değişkenlere göre değişimi: Anadolu, Akdeniz ve Karadeniz Teknik Üniversitesi Öğrencileri Üzerine Bir Uygulama. Anatolia Turizm Araştırmaları Dergisi, 12(2), 916.

Kuşluvan, S. ve Kuşluvan, Z. (2000). Perceptions and attitudes of undergraduate tourism students towards working in the tourism industry in Turkey. Tourism Management, 21(3), 251-269.

Kuşluvan, S. ve Kuşluvan, Z. (2003), Perceptions and attitudes of undergraduate tourism students towards working in tourism industry in Turkey, Tourism Management, 21, 251-269.

Lo, K., Lamm, F. (2005). Occupational stress in the hospitality industry: An employment relations perspective. New Zealand Journal of Employment Relations, 30(1), 23-47.

Owen, F.K., Kepir, D.D., Özdemir, S., Ulaş, Ö., Y1lmaz, O., (2012). Üniversite Öğrencilerinin Bölüm Seçme Nedenleri (*). Mersin Üniversitesi Ĕ̈itim Fakültesi Dergisi, 8(3), 135-151.

Presbury, R., Fitzgerald, A., Chapman, R. (2005). Impediments to improvements in service quality in luxury hotels. Managing Service Quality, 15(4), 357-373.

Poulston, J. (2009). Working conditions in hospitality: Employees' views of the dissatisfactory 
hygiene factors. Journal of Quality Assurance in Hospitality \& Tourism, 10, 23-43.

Roney, S.A. ve Öztin P. (2007). Career perceptions of undergraduate tourism students: A case study in Turkey. Journal of Hospitality, Leisure, Sport and Tourism Education, 6(1), 4 -17.

Şit, M. (2016). Türkiye'de turizm sektörünün istihdama katkısı. Akademik Yaklaşımlar Dergisi, 7(1), 101-117.

TUADER (2018). ÖSYM 2018-YKS turizm ön lisans ve lisans kontenjanları ve yerleştirme sonuçları istatistikleri ve raporu. http://www.tuader.org/osym-2018-yks-turizm-onlisans-ve-lisans-kontenjanlari-ve-yerlestirmesonuclari-istatistikleri-ve-raporu/

TÜRSAB (2018) Turizmin ekonomideki yeri diş ticaret açıklarını kapatmada payı. https://www.tursab.org.tr/tr/turizm-

verileri/istatistikler/turizmin-ekonomideki-yeri/disticaret-aciklarini-kapatmada-payi_916.html

Tüylüoğlu, T. (2003). Türkiye'de Turizm Eğitiminin Niteliği. Halkla İlişkiler ve Tanıtım Anabilim Dalı, Yayımlanmamış Yüksek lisans Tezi, Ankara Üniversitesi: Ankara

Üzümcü, T.P., Alyakut, Ö., Günsel, A. (2015). Turizm eğitimi alan öğrencilerin mesleğin geleceğine ilişkin bakış açıları. Balıkesir University the Journal of Social Sciences Institute. 18(33), 179-199.

Savickas, M. L. (1991). The meaning of work and love: career issues and interventions. Career

Development Quarterly, 39, 315-324.

Ünlüönen, K. ve Y. Boylu (2005). Anadolu Otelcilik Ve Turizm Meslek Liselerinde Öğrenim Gören Öğrencilerin Beklenti ve Algılamalarındaki Değişimin Karşılaştırılması (2000 - 2001 ve 2003 2004 Öğretim Yılları). Milli Eğitim, Üç Aylık Eğitim ve Sosyal Bilimler Dergisi, 33(166), 159174.

Querrier, Y. (1999). Organizational Behavior in Hotels and Restaurants: An International Perspective. Chichester: John Wiley.

Zengin, B. ve Uzut, İ. (2017) Lisans düzeyinde turizm eğitimi alan öğrencilerin üniversite tercihlerini etkileyen nedenler: İstanbul vakıf üniversiteleri örneği. Türk Turizm Araştırmaları Dergisi, 1(3), 16-30.

www.turkiyeturizm.com, Turizm öğrencileri gastronomiyi tercih ediyor, çevrimiçi (Erişim tarihi: 08.02.2019). 